\title{
Land subsidence and degradation of the Venice littoral zone, Italy
}

\author{
LAURA CARBOGNIN \\ Istituto per lo Studio della Dinamica delle Grandi Masse-CNR, San Polo 1364, \\ I-30125 Venice, Italy
}

\section{FRANCESCO MARABINI}

Istituto per la Geologia Marina, Area di Ricerca CNR, Via P. Gobetti 101, I-40129 Bologna, Italy

\section{LUIGI TOSI}

Istituto per lo Studio della Dinamica delle Grandi Masse-CNR, San Polo 1364, I-30125 Venice, Italy

Abstract The Venetian lagoon coastline is constituted by a narrow strip of land, the wholeness of which is vital for the existence of the historical city of Venice and the lagoon itself. Two processes have threatened the littoral zone: the erosive action of the sea and the land subsidence. Because of its particular setting, the fretful state of the littoral zone, is revealed by the negative evolution of the near-shore bottom slope. Five bathymetric surveys carried out in 1954, 1968, 1982, 1988 and 1992 are compared and the phenomenon of land subsidence is then analysed. Although the latter is not the primary cause of the increase in the bottom slope that has occurred, a certain correlation exists between the two processes. One may say that even a few centimetres of ground surface lowering may actually contribute to the destabilization of the littoral zone. Defence works are being undertaken.

\section{INTRODUCTION}

Land subsidence is a widespread phenomenon that may have either a natural or a maninduced origin.

Generally, geological subsidence has a slow evolution and does not arouse excessive trouble over short time periods. Subsidence induced by man's activity, on the contrary, is more frequent and has a more serious effect on the environment, mostly when induced by overexploitation of underground resources. From worldwide case histories, it appears that up to a few decades ago, the impact with the problem has in practice occurred a posteriori, with the direct observation of the amount and type of damage.

Environmental problems involving shallow coastal areas, often related to the erosive action of the sea and marine ingression, are made worse by land subsidence. Damage to buildings and port structures, displacement of pipes, flooding, salt-water intrusion and decay of the vegetation, are the more common environmental impacts caused by land subsidence all over the world (Fig. 1). 


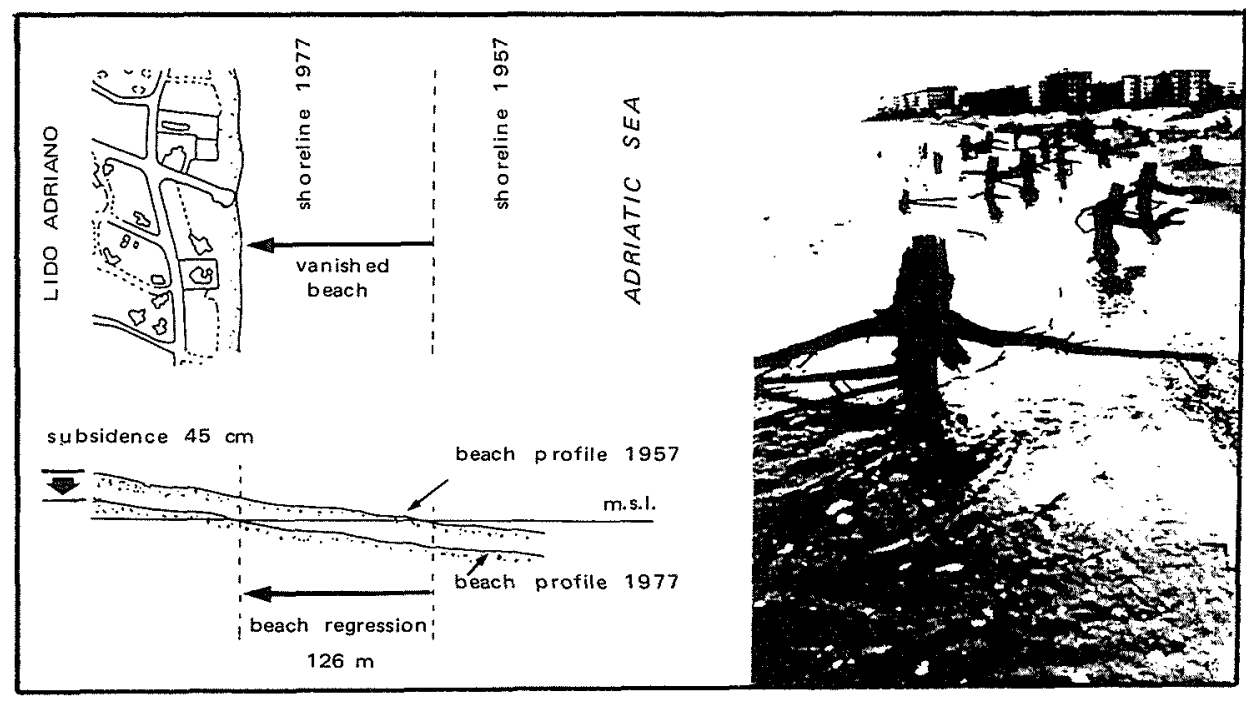

Fig. 1 Impact of land subsidence on the Ravenna coastal area, Italy, where the average beach slope is equal to $4 \%$. The shoreline regression which resulted has induced the sea water ingression and the decay of the wooded pine area lying just behind.

In addition when the coastal zone belongs to a lagoon environment the existence of which is strongly connected with the completeness of the littoral zone, the problem can assume very serious proportions.

This is the case of the Venice Lagoon, Italy, whose precarious condition is made even worse by the deterioration of the littoral zone which is of tremendous importance because it is the only slender bulwark against the attacking sea.

\section{THE VENETIAN LITTORAL ZONE}

The Venetian sandy littoral zone that extends for some $40 \mathrm{~km}$ and separates the lagoon from the Adriatic Sea, is divided into four portions (Chioggia, Pellestrina, Lido and Cavallino) by three inlets (Chioggia, Malamocco and Lido) which also allow water to flow in and flow out of the lagoon.

The crescent shaped coastline stretches northward from Chioggia to Lido and then turns to the east along the Cavallino beach. Because of this change in direction, the littoral zone strips are attacked by the sea with a different degree of energy and also undergo different amounts of sedimentation. The Cavallino littoral zone is mostly subjected to the northeast wind (bora) sea, meanwhile those of Lido, Pellestrina and Chioggia are subjected to both sirocco (southeast) and bora wind seas (Fig. 2).

The width of the four littoral zone strips varies from several kilometres at the two extremities (close to the outflows of rivers) to a few metres in the two central parts; in some places along the Pellestrina stretch, the beach is absent and only a rubble-mound seawall - locally called "murazzi" - is present.

The coastal equilibrium is influenced by both natural events and human interventions. 


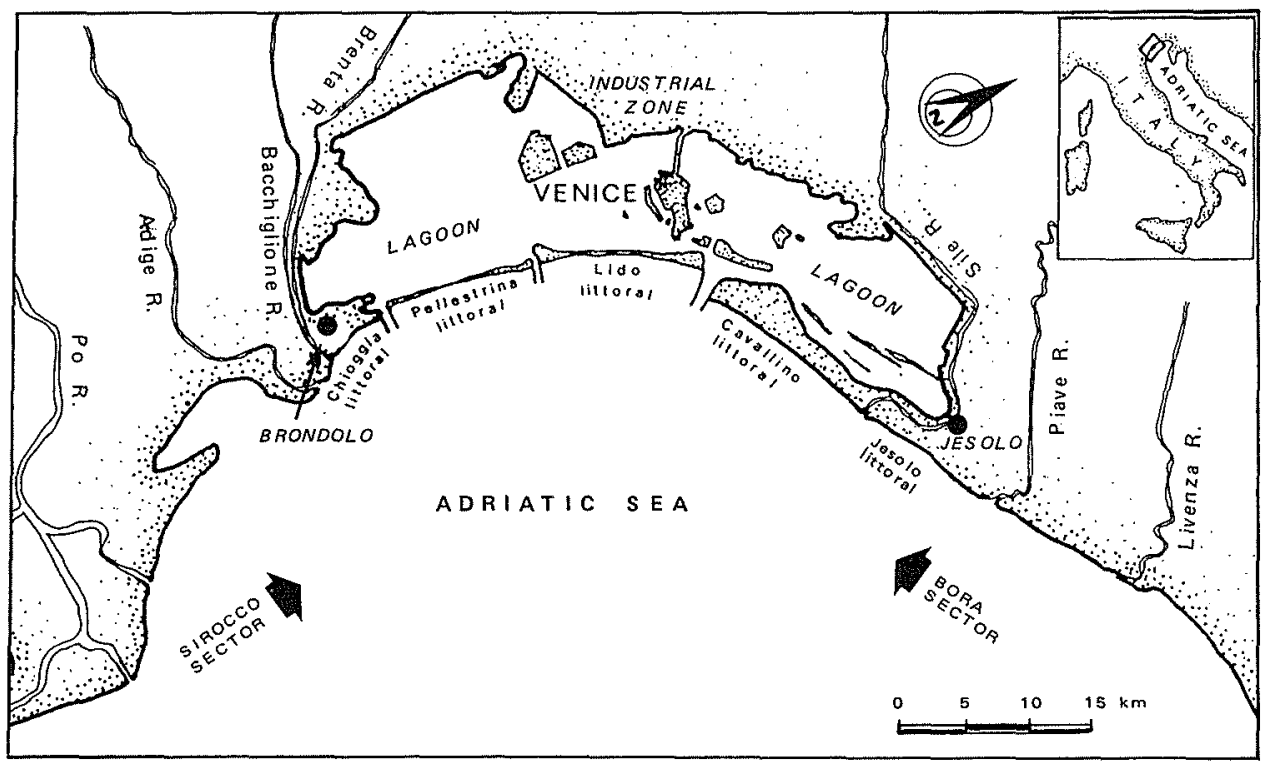

Fig. 2 Location and setting of the Venetian littoral zone strips.

Nowadays erosion is prevailing in the coastal area. The regional land subsidence which has occurred in this century, chiefly in the 1950 s and the 1960 s because of man's activity, has accentuated the already precarious situation of the littoral zone.

\section{Storms and sea level rise: recent developments}

It is known that a general tendency towards a climatic improvement exists in the Holocene with respect to the last glacial period. Within this phase one may distinguish climatic oscillations lasting some hundreds of years that alternate from cold-wet periods to warm and dry weather. Again, within these periods, other much shorter climatic variations with a $10-35$ year (20 on average) cycle repeating the alternation of cool-damp and warm-dry periods, are recognized. These short climatic fluctuations are known as the "Brückner cycles".

Climatic changes, either short or long, occur on a global scale but their effects are detectable on a regional scale too, and they are of primary importance in the evolution of the coastal zone. Also eustatic sea level changes can play an important role.

Regarding the Venetian littoral zone (as well as the whole upper Adriatic shallow coastal area) and focusing our attention on recent developments of these phenomena, we have observed changes in the sea and weather conditions that, following the Brückner cycles, have influenced the littoral zone evolution (Marabini \& Veggiani, 1991).

In particular, from the 1950s a new climatic cold/wet phase began and continued for about 20 years. An increase in rainfall, sea storms and flooding was recorded. In some places of the littoral zone, and mostly where the beach was wider and shore protection structures absent, a shoreline regression due to violent storm surges was observed (Carbognin et al., 1985). 


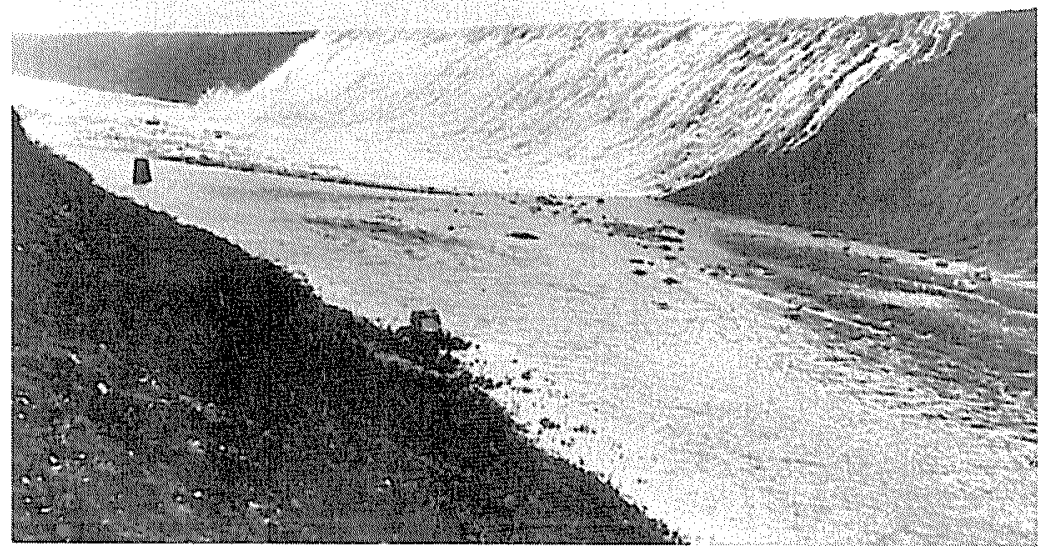

Fig. 3 Sea overtopping the littoral zone strip, 4 November 1966 (Courtesy of Cameraphoto, Venezia).

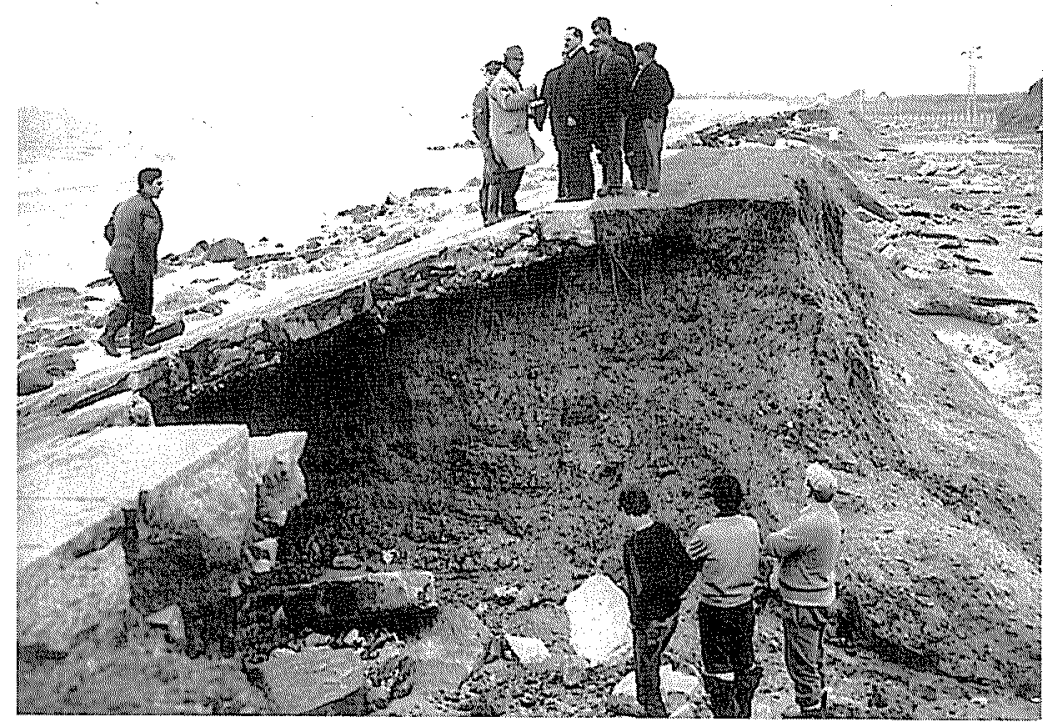

Fig. 4 Destruction of the "murazzi" at Pellestrina, after the very violent storm of 4 November 1966 (Courtesy of Cameraphoto, Venezia).

The sea and weather conditions, negative for the shore stability, culminated at the end of the 1960s with many storms, some of which were so severe that they overtopped the littoral zone strip in some places and destroyed the protection structures (Figs 3 and 4). 
In this period a contribution to the deterioration of the littoral zone was also given by land subsidence as described in the next section.

A quiescent phase in the adverse meteorological-marine conditions began in the 1970s. The 1980 s were characterized by a scarce rainfall and modest storm surges, typical of warm/dry periods and favourable to the coast equilibrium.

These observed climatic changes agree with the Brückner cycles.

With regard to the sea level rise (an important problem in shallow coastal areas presently under discussion at a worldwide scale), no evidence exists that this process has been felt in the Venetian lagoon in the last decades (Fig. 5).

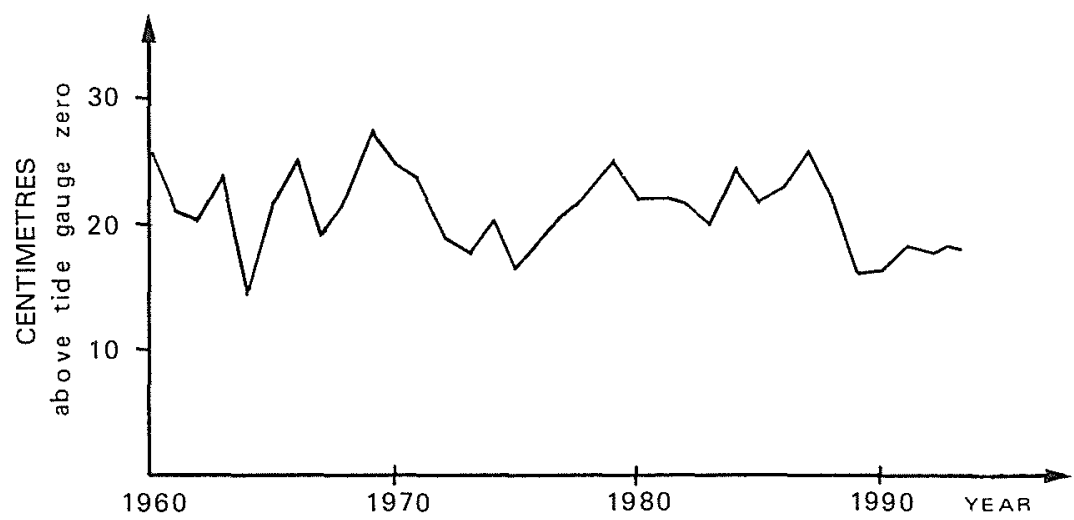

Fig. 5 Mean sea level at Venice from 1960 to 1994 (data after CNR and Comune di Venezia, 1995).

\section{Land subsidence}

The sinking of the ground surface that has affected the whole of the Venetian area has obviously also involved the littoral zone. Levels available for the littoral zone are fewer than those for the city of Venice. The subsidence of Venice in fact was investigated very carefully because of the worldwide importance of this historical city and the risk of its disappearance. Data on levels in this area have been reliably recorded since 1952 (chosen as the reference year). On the contrary only three surveys carried out in 1968, 1973 and 1993 are available for the entire littoral zone. For the Lido littoral zone it is only possible to compare five levels starting with 1961 . This is not only because the levels along the Lido belong to the principal levels for the city of Venice but also because of the importance of the Lido for tourism.

On account of the studies on the origin and the evolution of the Venetian land subsidence, of the rate and magnitude of sinking (relatively small even though vital for the city of Venice), and the available measurements for the entire territory, we have attributed to the whole littoral zone the same subsidence history as that reconstructed for Venice (Bortolami et al., 1985; Carbognin et al., 1981, 1984). Concerning the maninduced phenomenon, the main cause of the land sinking has been the intensive exploitation of artesian water that has occurred chiefly in the industrial zone located at the edge of the lagoon (see Fig. 2) and secondly in the Lido littoral zone for tourism needs. In the other littoral zone strips, the withdrawal of groundwater has always been 
of less importance and consequently it can be assumed that the induced subsidence has occurred at a smaller rate.

Regarding the subsidence of the Lido, the diagram comparing the variation in height of the benchmarks along the littoral zone in 1968, 1969 with the 1961 level is quite significant (Fig. 6). The most critical annual rate of subsidence was surveyed between 1968 and 1969, exactly as in the immediate hinterland where the subsidence "bowl" was found in the industrial zone. In the Lido area, the land subsidence touched the highest values in the lagoon basin with an average annual rate of about $1 \mathrm{~cm}$ year ${ }^{-1}$ between 1961 and 1969 (Fig. 7(a)) (Caputo et al., 1972).

From previous studies it is known that land lowering slowed down all over the region after 1970; in 1973 the subsidence came to a complete stop, and the 1975 levels even showed a significant rise equal to about $2 \mathrm{~cm}$ in the city of Venice (Carbognin et al., 1976). The 1973 levels clearly evidenced the positive phase of the sinking process along the entire littoral strip (the ground height of this area was not measured in 1975) (Fig. 7(b)).

Since that year, one can guess that only the natural compaction of the subsoil is occurring. This process has been quantified for the whole territory to be on average $0.4 \mathrm{~mm}$ year $^{-1}$ for this century.

In 1993, twenty years after the levels were measured over the entire region, a new precise survey covering the same area (mainland, industrial zone, city of Venice, areas surrounding the lagoon, and littoral zone) was carried out (Carbognin et al., 1994).

The variation of the surface height over a 20-year period indicates the actual trend of subsidence (Table 1). The comparison between the 1973 elevation (assumed as the base level) and that of 1993 is graphically presented for the whole littoral zone (Fig. 8) and for each strip (Fig. 9(a)-(d)). The coast stretching from Brondolo to Cavallino shows a land subsidence nearly similar; no significant differences appear even though the behaviour of ground elevation is pretty discontinuous. Going from the Cavallino to the Jesolo littoral zone further north, an increase in land subsidence occurs, ranging from $0.14 \mathrm{~cm}_{\text {year }}{ }^{-1}$ (mean value of the other littoral zone strips) to $0.21 \mathrm{~cm}_{\text {year }}^{-1}$ (mean value).

In the Chioggia beach sector without erosive-geomorphological problems (Fig. $9(\mathrm{a}))$, the sinking rate $\left(0.15 \mathrm{~cm} \mathrm{year}^{-1}\right)$ can be considered due to the natural phenomenon of sedimentation that occurs in the deltaic zone.

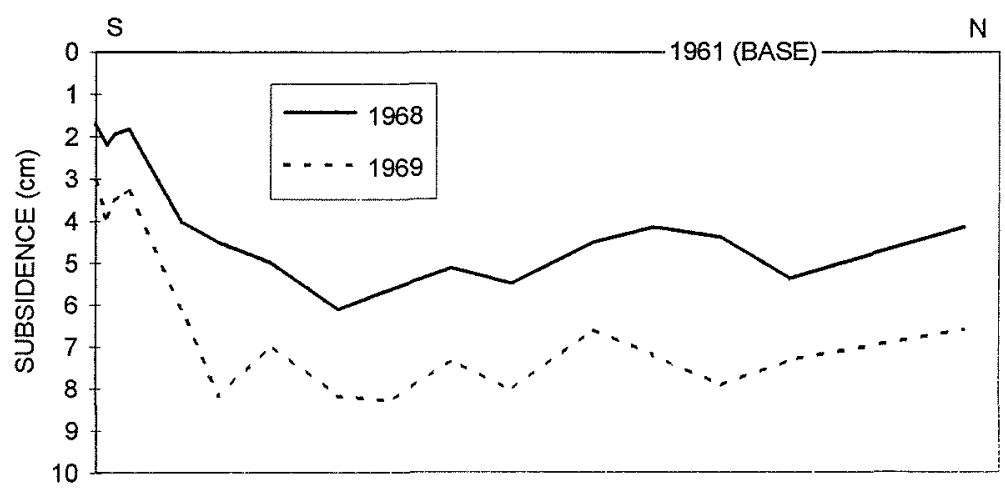

Fig. 6 Subsidence along the Lido littoral zone in the years 1968 and 1969 compared with 1961 . 

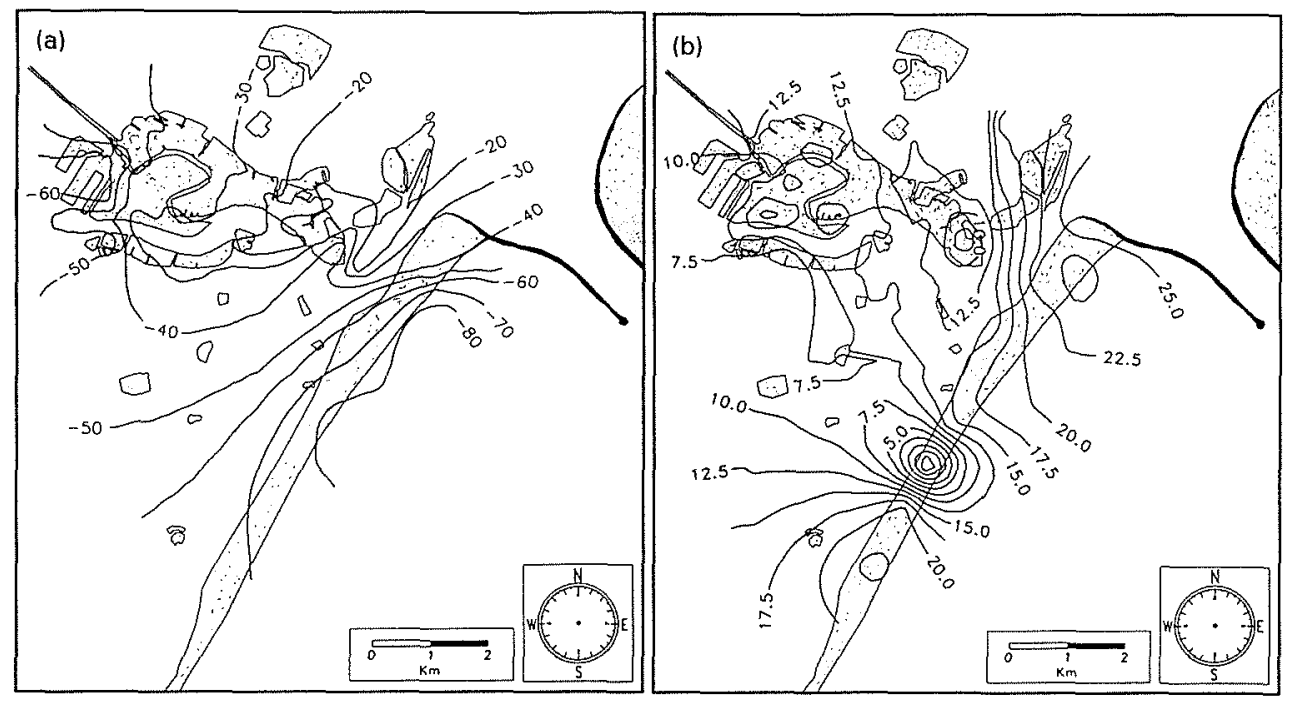

Fig. 7 Contour lines of subsidence (in $\mathrm{mm}$ ) for the historical centre of Venice and the Lido littoral zone in the periods: (a) 1961-1969 (re-drawn after Caputo et al., 1972) and (b) 1969-1973.

At Pellestrina (Fig. 9(b)), the most critical littoral zone with widespread shore protection structures, the maximum subsidence of about $5 \mathrm{~cm}$ in 20 years is found where the littoral zone is constituted only by the "murazzi". The negative peaks at the extremes correspond to the benchmarks established on the jetties where local structural settings have been observed (restoration work on these structures has been undertaken since 1994).

At the Lido (Fig. 9(c)) the maximum subsidence $\left(0.22 \mathrm{~cm}_{\text {year }}{ }^{-1}\right)$ has occurred in areas that were once agricultural before becoming residential in the 1980s. In any case, there is a notable change in the subsidence phenomenon (see also Fig. 7(b)).

The entire northern littoral zone, Cavallino-Jesolo, shows, as previously stated, the highest sinking values especially at Jesolo beach (Fig. 9(d)).

Table 1 Elementary statistics of the 1973-1993 land subsidence for the littoral zone stretches and the city of Venice.

\begin{tabular}{lllll}
\hline \multirow{2}{*}{ Levelling line } & \multicolumn{2}{c}{ Subsidence $(\mathrm{cm})$ 1973-1993: } & & \\
& Mean value & Annual rate & Max. value & Min. value \\
\hline Treviso-Mestre & -0.55 & -0.03 & -2.90 & 0.39 \\
Mestre-Venice & 0.27 & 0.01 & -0.91 & 1.62 \\
Venice (historical centre) & 0.30 & 0.02 & -3.58 & 1.64 \\
Mestre-Brondolo & -1.51 & -0.08 & -10.04 & 1.93 \\
Mestre-Jesolo & -2.04 & -0.12 & -7.97 & 0.30 \\
Littoral zones & -3.26 & -0.16 & -9.40 & -0.21 \\
\hline Chioggia littoral zone & -3.08 & -0.15 & -4.78 & -1.83 \\
Pellestrina littoral zone & -3.01 & -0.15 & -5.93 & -0.95 \\
Lido littoral zone & -2.49 & -0.12 & -4.45 & -0.21 \\
Cavallino-Jesolo littoral zone & -4.44 & -0.22 & -9.40 & -0.10 \\
\hline
\end{tabular}




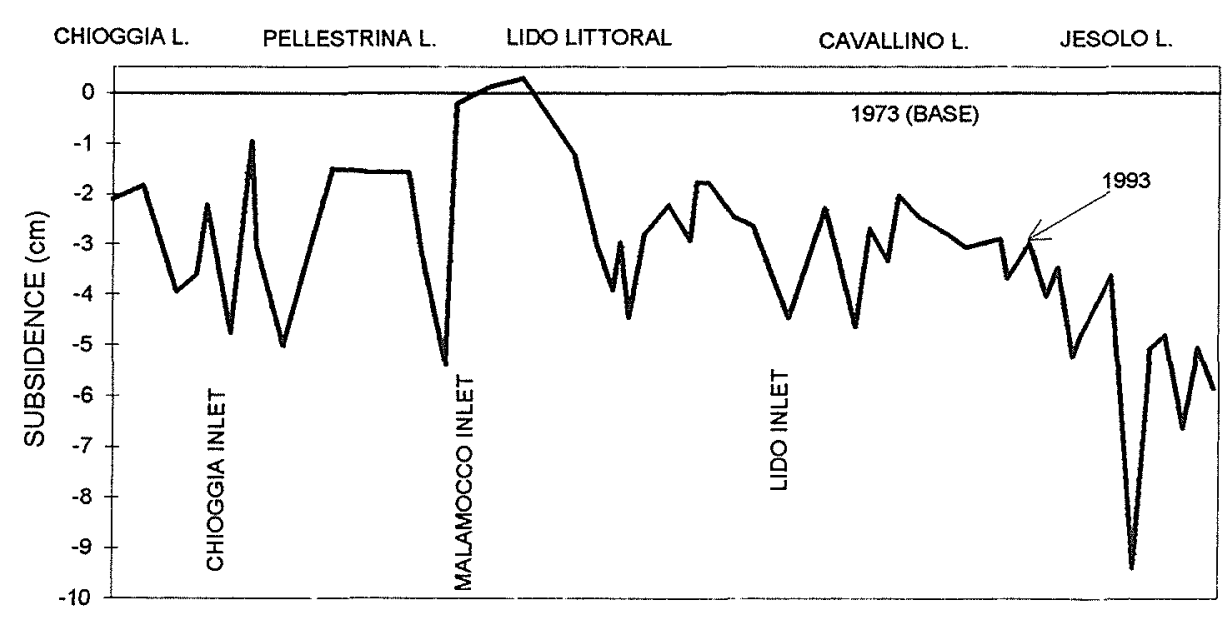

Fig. 8 Levelling profile of subsidence for the 20-year period (1973-1993) for the whole littoral zone from Brondolo to Jesolo.

In general, with respect to all areas of the Venetian region, along the littoral zone the greatest subsidence in the 20-year period was in 1993 levels. Not forgetting that the natural compaction of recent deposits is more active there than on the mainland.

\section{The effect of land subsidence on the erosion of the littoral zone}

The already precarious state of the littoral zone has been worsened by land subsidence.

Generally speaking it should be remembered that the present fluvial sediment yield to the sea is far less than in the past, and that the along-shore current moves less and less sandy material (Carbognin et al., 1985; Gatto, 1984).

The actual degenerative state of the littoral zone and the role played by land subsidence, is evident by following the evolution in time of the bottom slope near the shoreline. In fact, if in general land subsidence in shallow coastal areas induces a shoreline regression, this does not happen along the Venetian littoral zone where the "murazzi" act as a fixed barrier impeding the ingression of the sea. So the destructive action of the sea develops on the submerged littoral zone.

In Fig. 10, the comparison of bathymetric surveys for 1954, 1968, 1982, 1988, and 1992 from the shoreline up to the $5 \mathrm{~m}$ isobath is presented. In general a notable increase of the bottom slope from 1954 to 1968 is observed along the whole coastline, followed by a steady state with the 1968 critical values up to 1992 when local negative variations are observed. In particular, the southern Chioggia beach, which is the most stable coastal strip, does not show any significant variation from the surveys available up to 1982. Pellestrina, on the contrary, experiences quite a high increase of slope especially in 1968 and 1982. The 1988 and 1992 surveys provide evidence of very modest recoveries, and also show the maintenance of the slopes greater than $1 \%$ indicating the strong environmental degrading and instability. The near-shore bottom slope of the Lido underwent the maximum increase of $0.50 \%$ or more from 1954 to 1968, and other slight negative variations in successive times as the 1982, 1988 and 1992 bathymetric surveys show. Along the northern Cavallino beach, an evident 
a) CHIOGGIA LITTORAL

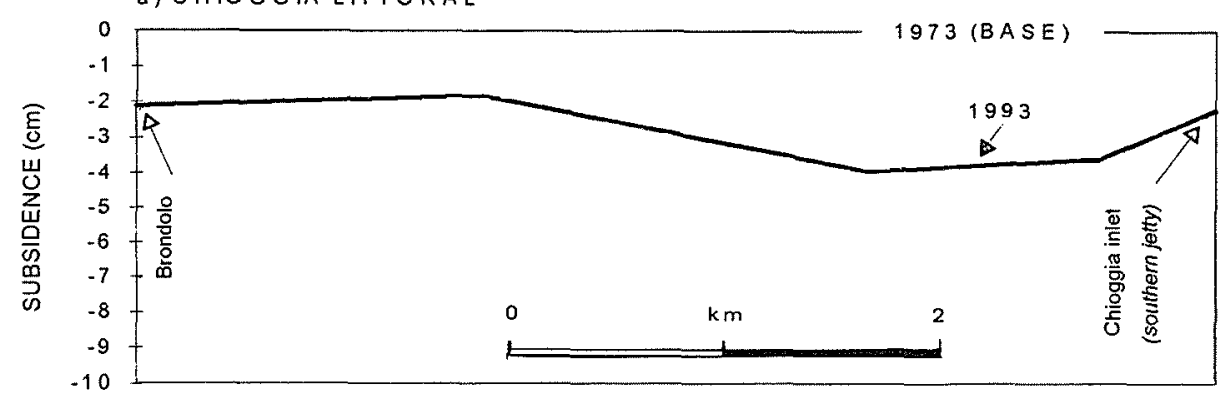

b) PELLESTRINA LITTORAL

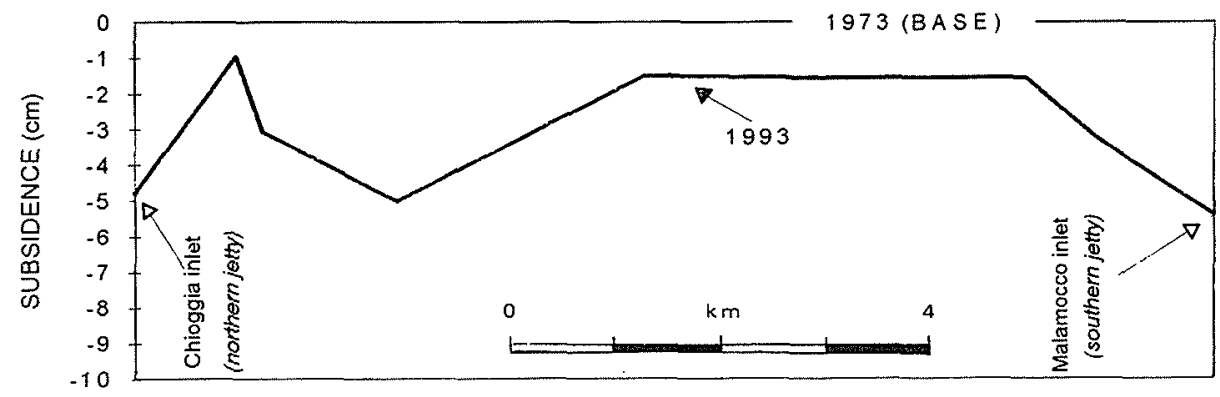

c) LIOO LITTORAL

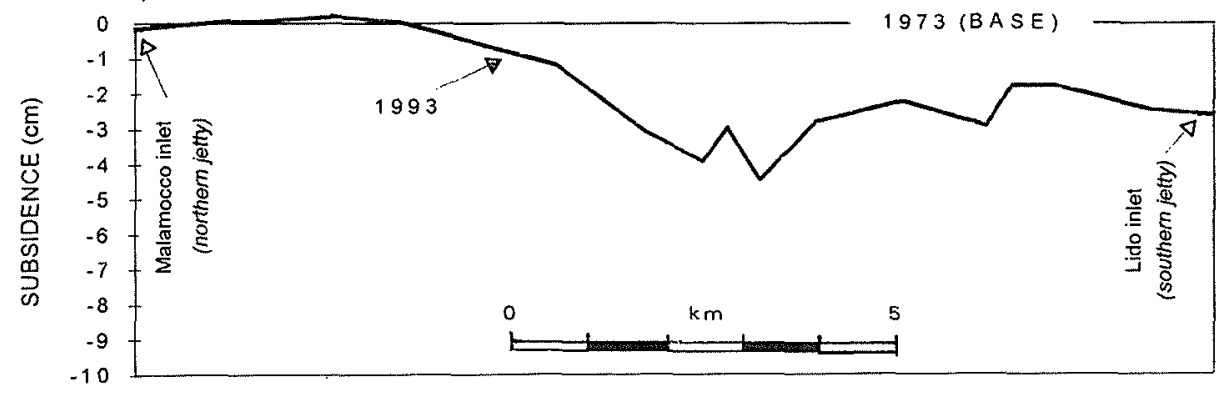

d) CAVALLINO LITTORAL and JESOLO LITTORAL

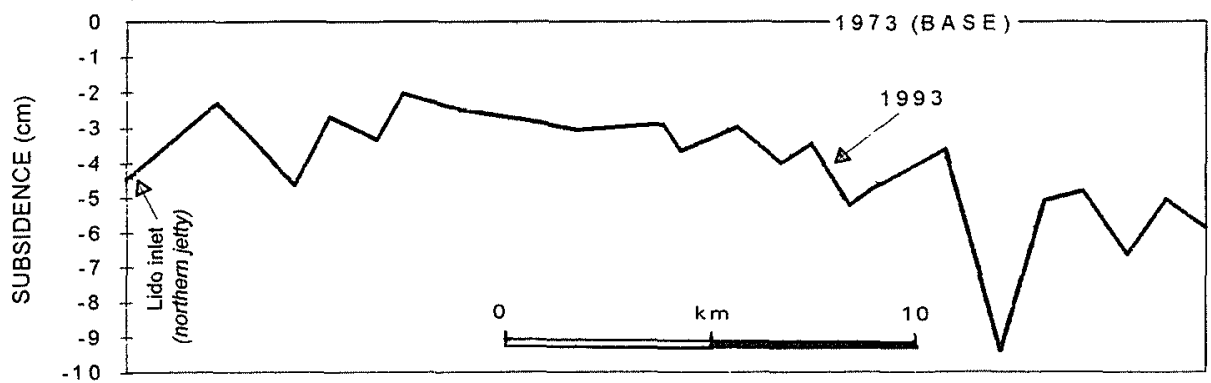

Fig. 9 The 1973-1993 subsidence profile for each littoral zone strip: (a) Chioggia, (b) Pellestrina, (c) Lido and (d) Cavallino-Jesolo. 


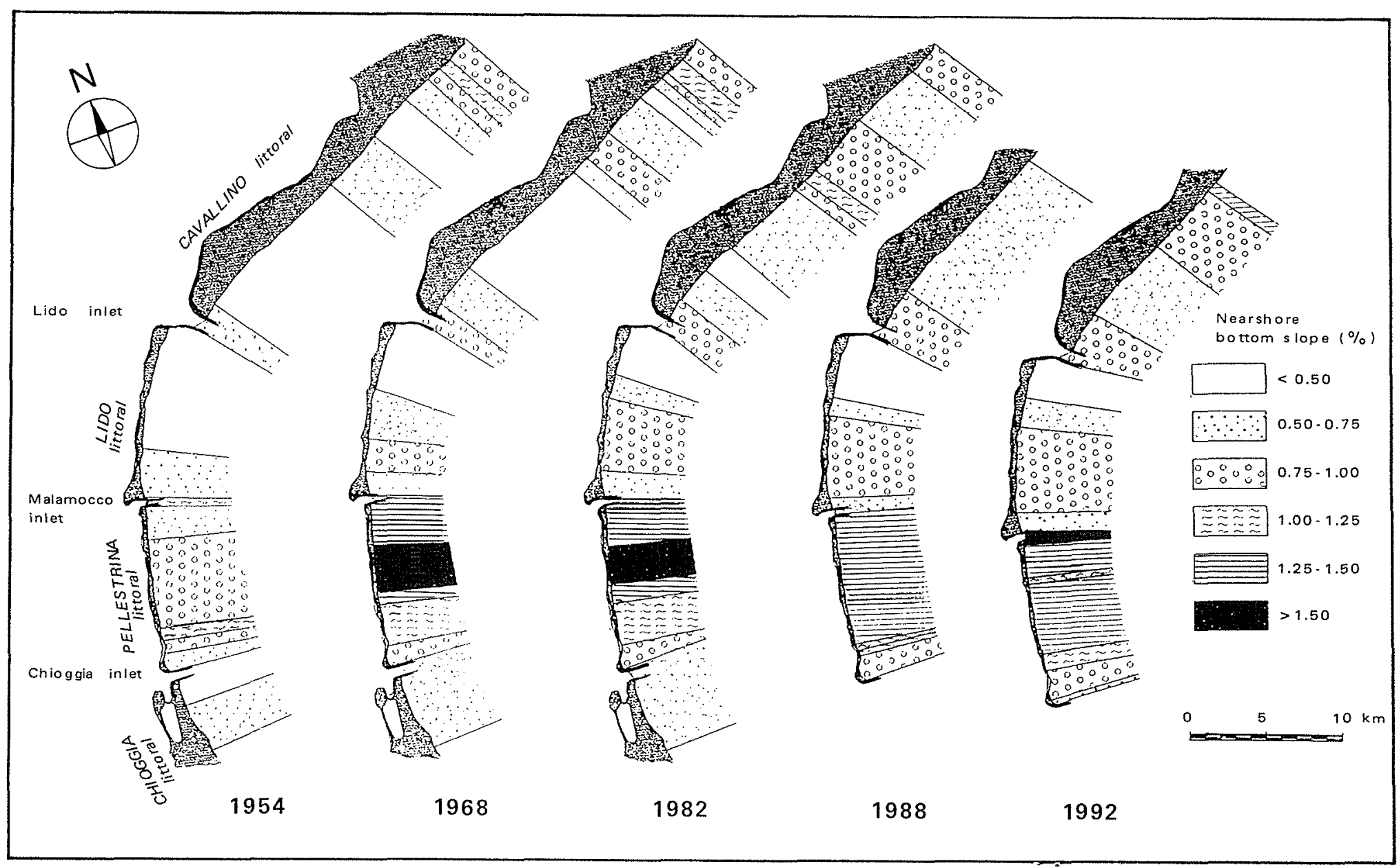


increase in sea bottom slope occurred up to 1982 followed by a slight recovery in 1988 and a new deepening in 1992.

Referring to the first span of time considered (1954-1968), the land subsidence occurred from the 1950s up to the end of the 1960s together with the high frequency of storm surges characteristic of this period, explain the deepening of near-shore bottom slope up to 1968. In the second period, 1968-1982, more favourable meteorological-marine factors, i.e. notable decrease of the southeast sea wind, and the stopping of land subsidence, occurred. The stability of the littoral zone condition has not recovered meaning that the deterioration is irrecoverable. The absence of negative climatic conditions and violent storm surges during the last 10 years do not explain the new deepening of the near-shore bottom slope surveyed in 1992 and especially along the northern littoral zone stretch. Vice versa one can partly justify this negative evolution considering the land subsidence at the Cavallino-Jesolo littoral zone that occurred in the 1973-1993 period. The considered values force us to think that this rather significant correlation is only qualitative.

Again, by analysing the 35 bathymetric profiles executed in 1992 (Ruol, 1994) we can see that a slight increase in near-shore bottom slope always corresponds to the subsiding points. This is true at the Cavallino littoral zone, where the phenomena are more evident, as well as along the other littoral zone strips.

\section{CONCLUDING REMARKS}

The recent land subsidence registered along the whole Venetian littoral zone, and mostly at its extremes, is in agreement with the rate of the natural compaction of recent sedimentation at the river deltas located at the north and south edges of the lagoon, and to the coastal sedimentation itself. Only locally can a partial contribution to land sinking be ascribed to human intervention (overload of new buildings and localized groundwater pumping).

Land subsidence is then occurring at a mean rate of $0.16 \mathrm{~cm}_{\text {year }}{ }^{-1}$, which is not alarming with respect to the past rates of up to $1 \mathrm{~cm}^{\text {year }}{ }^{-1}$ in the $1950 \mathrm{~s}$ and $1960 \mathrm{~s}$. Such a ground lowering is still considered of importance in this particular area of coast.

In fact, already in recent decades, relatively small subsidence has induced a permanent de-stabilization of the submerged littoral zone, and evidence of the correlation between the deepening of the near-shore bottom slope and land subsidence is found even today.

Moreover after the warm/dry period observed since the 1970s (according to the Brückner cycles), the situation of the Venetian littoral zone is today even more serious because in very recent times, a recommencement of heavy rainfalls and flooding has been noted. This leads us to believe that we are in the initial phase of a new cold/wet period. It is then probable that in the near future severe storm surges will attack the fragile Venetian littoral zone as in the recent past.

For these reasons some protective measures are being undertaken to reinforce the littoral zone strips. The solution chosen, after a number of expensive investigations and adequate mathematical models, is to install a number of groins opportunely spaced out. 
Acknowledgements The research was financially supported by the project "Sistema Lagunare Veneziano" and developed under the research groups 2.5 and 2.7. Particular thanks go to Mrs Jane Frankenfield Zanin for her help in the editing.

\section{REFERENCES}

Bortolami, G., Carbognin, L. \& Gatto, P. (1985) The natural subsidence in the Lagoon of Venice, Italy. In: Land Subsidence (ed. by A. I. Johnson, L. Carbognin \& L. Ubertini) (Proc. 3rd Int. Symp. on Land Subsidence, Venice, March 1984), 777-785. IAHS Publ. no. 151.

Caputo, M., Folloni, G., Gubellini, A., Pieri, L. \& Unguendoli, M. (1972) Survey and geometric analysis of subsidence in the region of Venice and its hinterland. Tech. Report no. 9. CNR-Lab. Studio Dinamica Grandi Masse, Venezia.

Carbognin, L., Gatto, P., Mozzi, G., Gambolati, G. \& Ricceri, G. (1976) New trend in the subsidence of Venice. In: Land Subsidence Symposium (Subsidence Terrestre) (Proc. 2nd Int. Symp. on Land Subsidence, Anaheim, December 1976), 65-81. IAHS Publ. no, 121.

Carbognin, L., Gatto, P. \& Mozzi, G. (1981) La riduzione altimetrica del territorio venezianoe le sue cause (Land elevation loss in the Venetian territory and its causes). Istituto Veneto di Lettere Scienze ed Arti, Rapporti e Studi VIII, 55-83.

Carbognin, L., Gatto, P. \& Marabini, F. (1984) The City and the Lagoon of Venice. A Guidebook on the Environment and Land Subsidence. Published on the occasion of the 3rd Int. Symp. on Land Subsidence (Venice, March 1984), printed by the Ufficio Stampa, Comune di Modena.

Carbognin, L., Gatto, P. \& Marabini, F. (1985) Erosive processes in the littoral of the Venice Lagoon (Italy). In: Coastal Zone 85 (ed. by O. T. Magoon, H. Converse, D. Miner, D. Clark \& L. T. Tobin) (Proc. Fourth Symp. on Coastal and Ocean Management, Baltimore, July 1985), vol. 2, 1587-1600. ASCE.

Carbognin, L., Marabini, F., Taroni, G., Teatini, P. \& Tosi, L. (1994) Altimetria recente del comprensorio lagunare veneziano. Un'analisi critica (Recent land elevation of the Venice Lagoon and hinterland. A critical analysis). Tech. Report no. 193. CNR-ISDGM, Venezia.

CNR \& Comune di Venezia (1995) Previsione delle Altezze di Marea a Venezia (Forecasting tide height in Venice). Venezia.

Gatto, P. (1984) Il cordone litoraneo della laguna di Venezia e le cause del suo degrado (The littoral zones of the Venice Lagoon and the causes of their degradation). Istituto Veneto di Lettere Scienze ed Arti, Rapporti e Studi, IX, 163-193.

Marabini, F. \& Veggiani A. (1991) Evolutional trend of the coastal zone and influence of the climatic fluctuations. Proc. Second International Symposium on Coastal Ocean Space Utilization (Long Beach, California, April 1991).

Ruol, P. (1994) Batimetrie del Litorale Veneziano rilievo 1992 e confronto con il 1988 (The 1992 bathymetric survey of the Venice littoral and its comparison with the 1988 one). Tech. Report no. 35, CNR-IGM, Bologna. 